\title{
Nordisk barnelitteratur - et nytt kunstforskningsspørsmål?
}

I april 2010 arrangerte de nordiske barnebokinstituttene sin første felles nordiske forskningskonferanse i Stockholm. Våren 2011 ble resultatene publisert i Barnboken og BLFT. Vi var også blitt enige om å fortsette samarbeidet og arrangere en felles konferanse hvert annet år. I august 2012 var det Oslos tur til å være vertskap. Konferansen ble holdt i Norsk barnebokinstitutts nyinnflyttede lokaler og samlet 60 deltakere fra hele Norden, flest nordmenn, men også mange dansker og noen svensker, i tillegg til deltakere fra USA og flere europeiske land.

Konferansetittelen, Nordisk barnelitteratur - et nytt kunstforskningsspørsmål? oppfordret deltakerne til å gjennomtenke det barnelitterære forskningsfeltet i lys av så vel globalisering og migrasjon, som den omfattende tekniske utviklingen som har preget de senere årenes medier. Hver av de tre konferansedagene var viet separate deler av denne omfattende problemstillingen.

19 foredrag ble presentert i løpet av konferansens tre dager, alle ble presentert i plenum, og diskusjonene var tilsvarende mange. Herværende konferansepublikasjon avslører at det å nytenke barnelitteraturforskningen er et pågående arbeid som i sin karakter må være uferdig, og som nettopp er avhengig av en bred og åpen diskusjon. Her publiserer vi fortløpende bare noen av de arbeidene som ble diskutert på konferansen.

Oslo, Stockholm, Aarhus i mai 2013

Kristin Orjasceter Norsk barnebokinstitutt

Nina Christensen

Center for børnelitteratur, Aarhus Universitet

Åsa Warnqvist Svenska barnboksinstitutet

Konferansen ble finanisert med bidrag fra Nordisk kulturfond

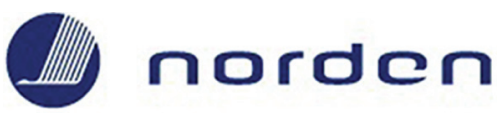

Nordisk Kulturfond 